\title{
Diversidade sexual e de gênero, geo(necro)política e alternativas heterotópicas um mundo melhor (ainda) é possível?
}
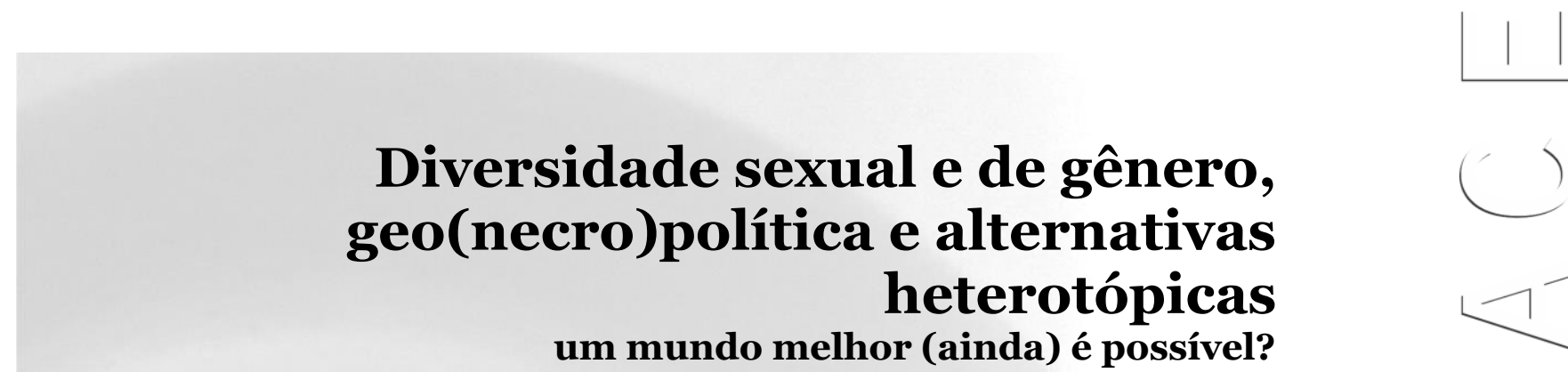

\author{
Fabiano Gontijo ${ }^{1}$ \\ Universidade Federal do Pará
}

Resumo: Que teorias sociais e políticas surgidas fora dos centros hegemônicos do pensamento podem contribuir para a compreensão das relações entre modernidade, capitalismo, Estados nacionais e moralidades, configurando-se, assim, como epistemologias, metodologias e ontologias científicas "outras", mais apropriadas para dar conta da geopolítica fortemente marcada por dispositivos transnacionais que, de modo necropolítico, ocultam globalmente a diversidade sexual e de gênero (ou as sexualidades não normativas)? Que alternativas por um mundo mais justo e feliz tais teorias, epistemologias, metodologias e ontologias científicas nos ajudariam a vislumbrar, no que diz respeito às expressões da diversidade sexual e de gênero, num futuro já em andamento? O artigo tem a pretensão de responder, ainda que parcialmente, a essas perguntas.

Palavras-chave: diversidade sexual; diversidade de gênero; geo(necro)política; alternativas heterotópicas.

\footnotetext{
${ }^{1}$ Atualmente é Professor Titular (Classe 8), vinculado ao Programa de Pós-Graduação em Antropologia (PPGA) e à Faculdade de Ciências Sociais (FACS) do Instituto de Filosofia e Ciências Humanas (IFCH) da Universidade Federal do Pará (UFPA). Coordenou o PPGA/UFPA de outubro de 2014 a abril de 2016 e é atualmente o seu vice-coordenador. Em 1990, começou seus estudos universitários de Ciências Sociais no Instituto de Filosofia e Ciências Sociais (IFCS) da Universidade Federal do Rio de Janeiro (UFRJ), terminando sua graduação em 1995 na França, na Université d'AixMarseille I (Université de Provence). Sua monografia de conclusão de curso, sobre as consequências (e impactos) sociais e culturais da AIDS junto a pessoas homossexuais cariocas, foi publicada em 1998 pela editora francesa GKC. Defendeu, em 1996, sua dissertação de mestrado interdisciplinar em Sociologia, História e Antropologia (núcleo de pesquisa "Sociologie, Histoire et Anthropologie des Dynamiques Culturelles") na Ecole des Hautes Etudes en Sciences Sociales (EHESS, Marseille), sob a orientação de Michel Agier e Jean-Louis Fabiani, tratando das expressões e experiências da diversidade sexual e de gênero formuladas através das situações ritualizadas do carnaval carioca. Sua tese de doutoramento em Antropologia Social (Anthropologie Sociale e Ethnologie), defendida em 2000 também na EHESS e orientada por Michel Agier intitula-se Carnaval, Gênero e AIDS, aprofundando as questões tratadas na dissertação de mestrado. Foi professor de Antropologia em instituições de ensino superior particulares dos estados do Rio de Janeiro e Espírito Santo e bolsista do CNPq no IFCS/UFRJ (modalidade recém-doutor) para desenvolver uma pesquisa sobre as "estéticas" marcadas pela diversidade sexual e de gênero nos rituais carnavalescos cariocas entre 2001 e 2002. Bolsista de Produtividade, Conselho Nacional do Desenvolvimento Científico e Tecnológico.
} 


\title{
Sexual and Gender Diversity, Geo(necro)Politics and Heterotopic Alternatives Is a better world (still) possible?
}

\begin{abstract}
That social and political theories arising outside the hegemonic centers of thought can contribute to the understanding of the relationships between modernity, capitalism, national states and moralities, thus configuring themselves as more appropriate "other" epistemologies, methodologies and scientific ontologies to account for the geopolitics strongly marked by transnational devices that, in a necropolitical way, globally hide sexual and gender diversity (or non-normative sexualities)? What alternatives for a fairer and happier world would such scientific theories, epistemologies, methodologies and ontologies help us to envision, with regard to the expressions of sexual and gender diversity, in a future already in progress? The article intends to answer, albeit partially, these questions.
\end{abstract}

Keywords: sexual diversity; gender diversity; geo(necro)politics; heterotopic alternatives.

\section{Diversidad sexual y de género, geo (necro) política y alternativas heterotópicas ¿Es (todavía) posible un mundo mejor?}

\begin{abstract}
Resumen: Que las teorías sociales y políticas que surgen fuera de los centros hegemónicos del pensamiento pueden contribuir a la comprensión de las relaciones entre modernidad, capitalismo, estados nacionales y moralidades, configurándose así como "otras" epistemologías, metodologías y ontologías científicas más apropiadas para dar cuenta de la geopolítica. fuertemente marcado por dispositivos transnacionales que, de manera necropolítica, ocultan globalmente la diversidad sexual y de género (o sexualidades no normativas)? ¿Qué alternativas para un mundo más justo y feliz nos ayudarían a vislumbrar tales teorías científicas, epistemologías, metodologías y ontologías, en lo que respecta a las expresiones de la diversidad sexual y de género, en un futuro ya en marcha? El artículo tiene la intención de responder, aunque parcialmente, a estas preguntas.
\end{abstract}

Palabras clave: diversidad sexual; diversidad de género; geo (necro) política; alternativas heterotópicas. 


\section{Os deuses devem estar loucos}

$\mathrm{O}$ primeiro Projeto de Lei (PL) da atual legislatura do Congresso Nacional brasileiro (2019-2023) tratou de tornar a bíblia, o livro sagrado cristão, "Patrimônio Nacional, Cultural e Imaterial do Brasil e da Humanidade"2 (Art. $\left.1^{0}\right)^{3}$. O PL, ainda em tramitação em 2021, é de autoria de um Deputado Federal que também é pastor evangélico e militar de carreira, o mesmo que, quando Deputado Estadual na Bahia, já havia conseguido tornar tal livro patrimônio imaterial daquele estado, nos arredores do carnaval de 20164. Em diversos municípios e outros estados brasileiros, a bíblia já é patrimônio cultural imaterial, assim como a música gospel evangélica5 e a Escola Bíblica Dominical, uma iniciativa de educação e doutrinação cristã surgida na Inglaterra e introduzida no Brasil por missionários escoceses na segunda metade do século XIX ${ }^{6}$. Inúmeros são, em cidades e até mesmo nas áreas rurais brasileiras, os monumentos e praças que homenageiam a bíblia ou outras representações cristãs, além das já tão corriqueiras referências a apóstolos, discípulos ou santos do panteão cristão (sobretudo católico) na toponímia oficial. Também oficialmente, jura-se "em nome de deus" nas posses de funcionários públicos de alto escalão, assim como de presidentes/a da República, governadoras/es, prefeitas/os, deputadas/os, senadoras/es e vereadoras/es, dentre outros, e todas as cédulas da divisa nacional, o real, ostentam a frase "deus seja louvado".

O primeiro PL da atual legislatura não foi aquele por acaso, já que parece nitidamente se inserir no âmbito de um determinado projeto de nação - confuso e desengonçado, mas bem estruturado econômica e politicamente - com sólidas articulações transnacionais. Também não foi o PL proposto por um deputado qualquer da base governista, mas um pastor e sargento, numa clara demonstração simbólica (mas, não somente) de que estava se reforçando, a partir daquele momento, com a legitimidade de um eleição reconhecida como democraticamente válida, a consolidação do poder político das igrejas cristãs e dos militares. Sendo assim, nada melhor do que inaugurar a atual legislatura sacralizando politicamente o livro de leis que, segundo os novos (?) membros do governo, estaria, desse modo, até mesmo acima da Constituição Federal. Inaugurava-se, com isso, não somente a nova legislatura do Congresso, mas também o governo de um Presidente cristão e ex-militar que se reconhece como ultraconservador. $\mathrm{O}$ resultado dessas eleições não teria sido esse se não fosse o generoso apoio do eleitorado cristão, sobretudo evangélico ou neopentecostal, em grande parte influenciado por igrejas e lideranças religiosas que, intensamente ancoradas nas obscuras profundezas econômicas e financeiras do país, já vinham lançando,

\footnotetext{
2 As/Os legisladoras/es brasileiras/os não têm competência para decidir sobre patrimônios "da humanidade", como solicitado pelo autor do PL em questão, o que seria competência da Organização das Naç̃̃es Unidas para a Educação, a Ciência e a Cultura (UNESCO). Quanto ao patrimônio cultural nacional, o órgão competente é o Instituto do Patrimônio Histórico e Artístico Nacional (IPHAN) para os tombamentos e/ou registros - faculta-se às/aos legisladoras/es a proposição de processos de patrimonialização e a demanda por proteção de bens patrimonializados ao IPHAN.

3 O PL e os detalhes de sua tramitação encontram-se disponíveis em: < https://www.camara.leg.br/propostaslegislativas/2190407 > . Último acesso em 18 de janeiro de 2021.

4 Ver: < https://www.bahianoticias.com.br/noticia/186155-assembleia-aprova-lei-que-declara-a-biblia-como-

patrimonio-imaterial-da-bahia.html > . Acesso em 18 de janeiro de 2021.

5 Ver: < https://www.supergospel.com.br/musica-gospel-e-inserida-na-lei-de-incentivo-a-cultura-e-reconhecida-comomanifestacao-cultural_3376.html >. Acesso: 19 de janeiro de 2021.

${ }^{6}$ Ver: < https://leismunicipais.com.br/a/pa/b/belem/lei-ordinaria/2020/961/961o/lei-ordinaria-n-9610-2020reconhece-como-patrimonio-cultural-de-natureza-imaterial-do-municipio-de-belem-a-ebd-escola-biblica-dominical-eda-outras-providencias >. Ver ainda: < https://agenciapara.com.br/noticia/16101/ > . Acesso em 19 de janeiro de 2021.
} 
cuidadosamente e sempre com muito êxito, desde a década de 1980, as suas grossas amarras no cais político nacional7.

O cais político é o atual caos social, instaurado com a solidificação paulatina do aparelhamento competente dos mais diversos órgãos, setores, postos estratégicos e instituições do Estado nacional (em seus três poderes) por religiosos e militares, (quase) sempre incompetentes ${ }^{8}$. A prova do êxito desse tipo de aparelhamento está, por exemplo, na escolha, para o principal Ministério responsável pela implementação (e fiscalização moral) da ideologia do governo, de uma pastora evangélica com vasta experiência de atuação em pautas conservadoras, tais como a promoção do "Programa Escola sem Partido" e a criminalização do aborto, contra a mudança da legislação sobre substâncias psicoativas, contra a teoria da evolução de Darwin, contra o casamento homoafetivo e a adoção por pessoas do mesmo sexo/gênero e a chamada "ideologia de gênero", antifeminista, instigadora do movimento antivacina em tempos de pandemia de COVID-19, além de ironizar a importância da fidelidade aos fatos quando mentiu sobre um título de seu currículo (fato, por sinal, que se repete com muita constância entre os membros de um governo marcado pelo negacionismo científico).

Com tamanho aparelhamento, não é difícil entender a importância que algumas personalidades políticas - antes de tudo, religiosas - dão ao registro de certas práticas como patrimônios culturais: ao tornar a bíblia ou a música gospel patrimônios imateriais, permite-se que os eventos associados possam receber financiamentos de empresas e corporações por meio de mecanismos de incentivos fiscais9. Até a política externa brasileira vem apresentando nítidos sinais desse aparelhamento: por exemplo, igrejas evangélicas brasileiras presentes no continente africano têm se servindo da nova postura do Ministério das Relações Exteriores para pautar os acordos de cooperação e avançar em suas agendas conservadoras naquele continente, com o apoio de parcelas do setor econômico de lá e de cá e da esfera política de lá - não sem conflitos locais. Assim, o governo - em todas as suas instâncias - e o Estado - em toda a sua instrumentalidade - parecem se unir a uma certa expressão religiosa do cristianismo e a uma certa experiência (neo)liberal do capitalismo para remodelar a "modernidade à brasileira" ao ungir, com o óleo do fundamentalismo, o projeto de nação com ambições transnacionais ${ }^{10}$.

Sugiro que esse projeto de nação não seja pensado como totalmente novo, instituído ex nihilo pelo governo de extrema-direita religioso e militar, mas em grande parte como a continuação de algo historicamente mais enraizado. Segue os preceitos da governamentalidade dos Estados nacionais que se universalizaram pelo mundo nos últimos dois séculos (de modos bastante particulares, claro) e, como consequência, segue também os princípios filosóficos modernos, de

\footnotetext{
7 Basta cruzar os dados das pesquisas de opinião pública sobre o desempenho do governo federal (como as realizadas por Datafolha ou XP/Ipespe) com os dados sobre a proporção de evangélicos no País e nos estados (como os do Instituto Brasileiro de Geografia e Estatística) para confirmar a importância do eleitorado evangélico na base do atual governo. ${ }^{8}$ Enquanto este texto estava sendo escrito, o Presidente dizia, em entrevista, que uma das principais mudanças ocorridas no País desde que assumiu o poder executivo é que agora há um Presidente que "acredita em Deus" e "respeita seus militares". Ver: https://www.msn.com/pt-br/noticias/brasil/sob-cr\%c3\%adticas-bolsonaro-invoca-lealdade-dasfor\%c3\%a7as-armadas-em-discurso-na-aeron\%c3\%a1utica/ar-BB1cVG8J?ocid=mailsignout\&li=AAggXC1. Acesso em 20 de janeiro de 2021.

${ }_{9}$ Sobre as dívidas e o benefícios das igrejas, ver: https://brasil.elpais.com/brasil/2019-12-26/igrejas-devem-mais-de460-milhoes-de-reais-ao-governo.html. Acesso em 21 de janeiro de 2021.

${ }^{10}$ Fundamentalismo, pois nos últimos anos, percebe-se a intensificação de ataques a espaços religiosos não cristãos por todo o Brasil (principalmente, de religiões de matriz africana), assim como o surgimento de facções criminosas (inclusive, atuantes no tráfico de entorpecentes e nas milícias ilegais) que se auto-intitulam evangélicas e agem "em defesa" da moralidade religiosa ao proibirem as atividades de religiões de matriz africana em seus territórios de influência (ver: https://extra.globo.com/casos-de-policia/traficantes-evangelicos-fecham-pacto-com-milicia-para-expandir-complexode-israel-24821015.html e https://www.cartacapital.com.br/sociedade/como-o-crime-organizado-tem-exploradobeneficios-concedidos-a-igrejas-para-operar-seus-negocios-ilegais/ ). Acesso em 20 de janeiro de 2021.
} 
inspiração euro-norte-americana, das Constituições Políticas desses Estados nacionais que firmam as moralidades vigentes, inclusive com referências religiosas cristãs. É assim que, por exemplo, ao estabelecer os valores para uma "sociedade fraterna, pluralista e sem preconceitos", a Constituição Federal brasileira de 1988 foi promulgada "sob a proteção de Deus", de acordo com o que se lê em seu Preâmbulo, embora se afirme, nem sempre com a devida firmeza, que o Estado seja laico, neutro e leigo, como se deduz dos Artigos $5^{0}$ e 19.11

Ora, prega-se a laicidade do Estado, mas a governamentalidade se sustenta historicamente em moralidades religiosas, discursividades médico-científicas e normatividades jurídico-morais modernas importadas que, no Brasil como em tantos outros países, instituem (naturalizam e essencializam) a heteronormatividade, o dimorfismo sexual, o binarismo de gênero e a heterossexualidade compulsória, em detrimento da diversidade sexual e de gênero, como bases biopolíticas de sustentação das ideologias nacionais. Em nível global, os dispositivos biopolíticos assim instituídos serviram para disciplinar os corpos em função da produção capitalista e da reprodução dos/as trabalhadores/as nas sociedades burguesas. As discursividades, sem deixarem de ser maquiadas pela moralidade religiosa e pastoral - embora, em teoria, se opusessem à teologia cristã -, contribuíram para a legitimação dos projetos expansionistas coloniais e imperialistas europeus e capitalistas euro-norte-americanos ao longo dos séculos XIX e XX - projetos imbuídos de uma declarada missão civilizatória e disciplinadora dos corpos sob os auspícios da governamentalidade biopolítica moderna (alguns desses termos serão definidos mais adiante).

Diante disso, sugere-se às/aos leitoras/es, num primeiro momento, algumas questões sobre as relações entre modernidade, capitalismo, Estado e moralidades. Em seguida, convida-se a um passeio por conceitos e categorias que ajudem a entender a estranha promiscuidade das relações entre Estado e capitalismo que se sustentam em modos particulares de governamentalidades modernas baseadas em moralidades silenciadoras da diversidade sexual e de gênero. Enfim, após o passeio, talvez se chegue a um cais ainda (mais) caótico, mas com a possibilidade de vislumbrar alternativas, utopias e heterotopias no horizonte (pelo menos, espero).

\section{Questões para Respostas}

Como as relações entre modernidade, capitalismo, Estados nacionais e moralidades moldam as coesões morais que estão na base das ordens sociais globalmente predominantes? Que impactos globais e locais têm as coesões morais e as ordens sociais consequentes sobre as expressões da diversidade sexual e de gênero? ${ }^{12}$ Por meio de que mecanismos, dispositivos, tecnologias, instrumentos, estratégias e símbolos se fez hegemônica a ideologia segundo a qual o binarismo de gênero, o dimorfismo sexual e a heterossexualidade compulsória são "natu-

\footnotetext{
${ }^{11}$ Ver: < http://www.planalto.gov.br/ccivil_03/constituicao/constituicao.htm >. Acesso em 19 de janeiro de 2021.

${ }^{12}$ Experiências da diversidade sexual e de gênero se referem às práticas e identidades sexuais e/ou de gênero e suas múltiplas dinâmicas sociais e culturais (às vezes será usado o termo "expressão" para dar ênfase ao caráter eloquente das práticas e identidades). Por sexualidade não normativa designam-se as experiências consideradas localmente como não correspondendo às expectativas sociais, morais e, às vezes, jurídicas estabelecidas e, portanto, passíveis de alguma forma de regulação. Enfim, sexualidade alternativa diz respeito às experiências "outras" em relação às normativas, mas não necessariamente passíveis de enquadramento. Homossexualidade (assim como os termos lésbica, gay, bissexual, transexual, transgênero/a/e, intersexual etc.) é o termo "moderno" médico-científico mais usado pelas instâncias internacionais, também amplamente usado por governantes e ativistas. Prefere-se diversidade a dissidência, por se acreditar que a diversidade engloba tanto as experiências e expressões dissidentes, quanto aquelas normativas. Acredita-se também que o uso de diversidade no singular engloba o conjunto de todas as formas, experiências e expressões (logo, não seria necessário aqui usar “diversidades”).
} 
rais", ocultando-se, assim, a realidade histórica da diversidade sexual e de gênero pelo mundo afora? De que modo a razão médico-científica e a normatividade jurídico-moral modernas de origem euro-norte-americana se associam a certas moralidades religiosas (em particular, dos grandes complexos religiosos monoteístas caracterizados pelo cristianismo, o judaísmo e o islamismo) para nutrir aqueles mecanismos, dispositivos, tecnologias, instrumentos, estratégias e símbolos e, desse modo, sustentar a legitimidade dos modelos de governamentalidade biopolítica dos Estados nacionais e do capitalismo transnacional na contemporaneidade?

Que teorias sociais e políticas ou, mais precisamente, antropológicas, surgidas fora dos centros hegemônicos do pensamento (ou seja, no Sul Global), em conjunto com algumas teorias difundidas a partir desses centros hegemônicos, podem contribuir para a compreensão das relações entre modernidade, capitalismo, Estados nacionais e moralidades, configurando-se, assim, como epistemologias, metodologias e ontologias científicas "outras", mais apropriadas para dar conta da geopolítica fortemente marcada por aqueles mecanismos, dispositivos, tecnologias, instrumentos, estratégias e símbolos transnacionais que, de modo necropolítico, ocultam globalmente a diversidade sexual e de gênero (ou as sexualidades não normativas)? Que alternativas por um mundo mais justo e feliz tais teorias, epistemologias, metodologias e ontologias científicas nos ajudariam a vislumbrar, no que diz respeito às expressões da diversidade sexual $\mathrm{e}$ de gênero, num futuro que, a meu ver, já começou? ${ }^{13}$

Não é possível responder satisfatoriamente às questões acima no âmbito deste artigo, nem é esse o meu intuito. Trata-se de apresentar um pequeno esboço ensaístico produzido a partir das experiências etnográficas oriundas da pesquisa multissituada que venho realizando há alguns anos ${ }^{14}$, na esperança de instigar as reflexões sobre as consequências das relações complexas, multifacetadas e obscuras entre modernidade, capitalismo, Estados nacionais e moralidades e seus mecanismos, dispositivos, tecnologias, instrumentos, estratégias e símbolos de ocultamento das expressões da diversidade sexual e de gênero.

\section{Críticas, reflexivas e emancipadoras}

De fundamental relevância são as bases críticas proporcionadas pelas teorias sociais e políticas latino-americanas em particular e, mais geralmente, das "antropologias do sul” e do pensamento pós-colonial (latino-americano, africano e indiano, mas não somente), para a produção de reflexões que ajudem a dar conta das perguntas elencadas acima.

Para Quijano (2000), a matriz colonial de poder se impõe com o colonialismo e o processo de colonização europeu e perdura até os dias de hoje, sob a forma da colonialidade do poder, por meio do controle dos quatro domínios básicos da existência humana: o controle do trabalho; o controle da autoridade coletiva ; o controle do sexo, ou seja, do gênero e da sexualidade (com a imposição e a naturalização da heteronormatividade, do modelo de família cristã como célula básica da vida social, etc.); e enfim, o controle do conhecimento e da subjetividade, performando as colonialidades do saber e do ser.

${ }_{13}$ Para os objetivos deste artigo, considera-se o Norte Global como o conjunto de países globalizadores em suas ações de perpetuação do colonialismo e do imperialismo, por meio do capitalismo, enquanto o Sul Global é formado por países e regiões que reagem, de alguma forma, às imposições do Norte Global, às vezes produzindo criativamente formas políticas particulares e pautando alternativas globais contra o universalismo. Ver, a esse sujeito, Ballestrin (2017), CastroGómez (2019) e Santos (2007).

${ }_{14}$ Agradeço ao Conselho Nacional de Desenvolvimento Científico e Tecnológico pela bolsa de produtividade. 
Embora os elementos e as relações dessa matriz já existissem antes da colonização europeia, o colonialismo e o imperialismo os arranjaram particularmente e os impuseram ao mundo não europeu através do expansionismo europeu, principalmente com o apoio, segundo Mignolo (2008), do patriarcado (que regularia as relações sociais de gênero e os desejos sexuais com relação à autoridade, à economia e ao conhecimento) e do racismo (que regularia as classificações da diversidade humana com base no "sangue" e na "cor da pele"). A modernidade seria a fusão das experiências da colonialidade e do colonialismo/imperialismo com as necessidades do capitalismo, criando um universo específico de relações intersubjetivas de dominação sob a hegemonia eurocentrada.

Discutindo a invenção do "paradigma sexual binário", Lugones (2008) afirma que o dimorfismo sexual (e o binarismo de gênero e a heteronormatividade, eu acrescentaria) representaria o "lado visível" de uma espécie de sistema moderno-colonial de gênero constituído no âmbito da matriz colonial de poder, ao passo que, às margens do sistema, encontra-se em estado de violência o "lado oculto”, aquele representado por todas as situações não binárias e fluidas - das sexualidades alternativas, por exemplo - que caracterizam a diversidade sexual e de gênero. A autora analisa a intersexualidade para demonstrar, em nível global, o quanto o gênero antecede o biológico na determinação desse sistema: historicamente, o capitalismo eurocentrado reconheceu o binarismo sexual somente para homens e mulheres brancos/as e burgueses/as, já que os/as colonizados/as (indígenas das Américas, africanas/os, asiáticas/os etc.) eram tratadas/os muitas vezes como aberrações, até mesmo não binárias, que precisariam ser corrigidos/as pela "civilização", assim como as pessoas intersexuais em geral. Desse modo, "[...] as correções substanciais e cosméticas sobre o biológico deixam claro que o "gênero" antecede os traços "biológicos" e os preenche de significado"15 (2008: 31). Ora, a intersexualidade não é, pois, universalmente objeto de "correção" (basta ver a literatura antropológica sobre o assunto), pois isso aconteceria somente no contexto do sistema moderno-colonial de gênero que se aprimorou na Europa e se expandiu com a colonização a partir do século XVI e a conseguinte imposição teleológica do binarismo - ou melhor, daquele binarismo essencial definido na Europa de então.

No contexto africano pós-colonial, Oyěwùmí (1997) denuncia a naturalização da subordinação universal das mulheres e a essencialização do patriarcalismo supostamente primordial da África como efeitos da colonização - já que nem mesmo o gênero, segundo a autora, teria existido em alguns contextos do continente africano antes da colonização europeia. Analisando a realidade nigeriana, Oyěwùmí afiança que a colonização europeia (outras/os acrescentariam a colonização islâmica) teria imposto, de um lado, a hierarquia racial com a consequente inferiorização das/os africanas/os e, de outro, a hierarquia de gênero com a inferiorização das mulheres - e o ocultamento da diversidade sexual. Assim, as mulheres teriam perdido seus tradicionais papeis de liderança política, a propriedade da terra e outros importantes espaços econômicos, enquanto os homens tornar-se-iam os detentores do espaço público, o que teria desembocado na incorporação ao sistema moderno-colonial de gênero sem grandes dificuldades por parte dos homens africanos, já que seus poderes seriam consideravelmente aumentados.

15 Tradução livre do espanhol: "Las correcciones sustanciales y cosméticas sobre lo biológico dejan en claro que el "género" antecede los rasgos "biológicos" y los llena de significado." 
Amadiume (1997), por sua vez, confirma essa perspectiva, ao tratar da maneira como as mulheres de uma determinada região rural da Nigéria tiveram seu status de poder transformado pelo colonialismo e pelas religiões (cristã e islâmica) e mantido no período pós-colonial pelo sistema educacional. A autora sugere que as mulheres terceiro-mundistas deveriam desafiar politicamente os governos, denunciando os arbitrários culturais e históricos que sustentam os sistemas patriarcais e os Estados nacionais para resgatar o poder que tinham antes da colonização, agora sobre novas bases.

Algo parecido, sobre as mudanças nas relações de gênero e o incremento dos privilégios masculinos no contexto da persistência do sistema modernocolonial de gênero, é observado também entre povos indígenas da América do Sul por Paredes (2014) - que alertou para o "entronque patriarcal" ou as formas patriarcais de opressão existentes antes da colonização e que se juntaram àquelas impostas pelos colonizadores - e Segato (2013) - que propôs a necessidade de se diferenciar a realidade da "dualidade" de gênero complementar das sociedades indígenas em relação à imposição colonial do "binarismo" opressor ${ }^{16}$. Contrariamente a Oyěwùmí e Lugones, Paredes e Segato não negam a existência de algo como o gênero no período pré-colonial.

Segundo Segato (2013), evidências históricas e relatos etnográficos (como os de sua autoria) identificam que havia uma organização patriarcal em sociedades indígenas e afro-americanas que ela qualifica como de "baixa intensidade", quando contrastada com a organização patriarcal que passa a se impor com a colonização, de "alta intensidade". Resistindo à "alta intensidade", surgem movimentos liderados por mulheres brancas, burguesas e ocidentais reivindicando a "equidade de gênero" e/ou a "igualdade de gênero", o que, segundo Paredes (2014), esvazia o potencial político do conceito de gênero, assim como acontecia com o conceito de classe: nas organizações patriarcais de "baixa intensidade", trata-se não de ver homens e mulheres como iguais ou diferentes (como nos feminismos ocidentais), mas de pensa-las/os em relação à comunidade (no sentido da complementaridade e da reciprocidade entre os/as/es componentes); assim, não se trata de ser homens, mulheres ou outras possibilidades, mas pessoas (ou seres) que formam, juntas, uma comunidade.

Paredes (2014) e Segato (2013) não propõem, com isso, a volta a uma suposta tradição pré-colonial, já que essa tradição também era marcada pela desigualdade. Nem tampouco conservar o gênero na ideia de "equidade" ou na de "igualdade" - valores modernos europeus - ajudaria a superar a opressão, segundo as autoras, pois as estruturas de poder - modernas e europeias - seriam mantidas. Ao contrário, propõem que se transcenda o gênero, tal como formulado e difundido pela modernidade no pacote da matriz colonial de poder: "[o] que se quer com o feminismo [comunitário] é não ser mais femininas, nem masculinos"17, avança Paredes (2014).

Ou seja, seria necessário a transcendência, do mesmo modo, da heteronormatividade, como sugerido nitidamente na perspectiva queer e, em particular, nas sua versão cabocla (Fernandes e Gontijo, 2016; Gontijo, 2019a). A partir de Curiel (2011) - e também Wittig (2006) -, penso que a heteronormatividade funcionaria como um regime politicamente definido, cuja ideologia repousaria precisamente na naturalização de "uma” diferença sexual: o gênero, tal qual elaborado na modernidade euro-norte-americana, naturalizaria a diferença sexual,

${ }_{16}$ Tlostanova (2008) também chega a conclusões semelhantes ao analisar o contexto das ex-colônias soviéticas e/ou russas não europeias.

${ }_{17}$ Tradução livre do espanhol: "Lo que se quiere desde el feminismo [comunitario] es ya no ser más ni femeninas ni masculinos." 
colocando, logo, a natureza como causa da diferença (assim como foi feito, por exemplo, com a raça). A ideologia assim constituída enquanto heteronormatividade ocultaria o que aconteceria de fato nos planos econômico e político que se legitimam através dessa ideologia. Indo além do que foi proposto por Curiel (2011), nesse sentido, seria a opressão que criaria o sexo, o gênero e, por tabela, a heteronormatividade, não o contrário, donde a necessidade de romper com essa ideologia como uma das marcas da modernidade euro-norte-americana. A ruptura seria possível no contexto das modernidades "outras", como as latinoamericanas, por exemplo, como avançado por Cusicanqui (2010) ou Gargallo (2014), ou ainda, complementarmente, no contexto de uma teoria crítica da democracia radical e do republicanismo, como indicado por Castro-Gómez (2019).

Para Gargallo (2014), não se deve confundir "Modernidade" com "modernidade emancipada". A primeira é plural - Cusicanqui (2010) chama atenção para a modernidade dos povos indígenas, por exemplo. Já a modernidade emancipada, por sua vez, caracterizar-se-ia pelo fato de que houve a emancipação do indivíduo em relação ao coletivo, na passagem da Europa medieval para o Iluminismo, "um" indivíduo construído como proprietário, chefe de uma família nuclear na qual os trabalhadores não remunerados são as mulheres, que também não são sujeitos de direitos; a modernidade emancipada seria a projeção dos ideais produzidos pelas classes proprietárias europeias sobre o resto do mundo que construiu, por exemplo, um sistema escolar voltado para a exclusão das experiências e conhecimentos que não pertenciam ao seu projeto - ideais que incluíam a produção intelectual, religiosa, jurídica, pedagógica e artística que sustentava e justificava a exploração econômica dos povos do resto do mundo.

$\mathrm{Na}$ América colonizada, as elites e classes médias reproduzem esses ideais, aplicando o colonialismo interno, como sugerido por González Casanova (2006) - uma modalidade das colonialidades do saber e do ser? -, sobre todas as outras formas de ser que não aquelas baseadas na "modernidade emancipada", em prol das ideias vagas e individualistas de "progresso" e "desenvolvimento" - e também de "igualdade" e "equidade". É aqui que, a meu ver, se imiscui a negação da diversidade sexual e de gênero e a instauração da suposta naturalidade do binarismo de gênero e do dimorfismo sexual, ou seja, a heteronormatividade, e as moralidades subjacentes (ainda fortemente ancoradas numa certa interpretação do cristianismo). Para Gargallo (2014), a Modernidade, apesar da dominação do modelo da "modernidade emancipada", inclui momentos, espaços e geografias que não são redutíveis a uma experiência histórica única, nem a um universo epistêmico único, pois a Modernidade seria precisamente um conjunto de modernidades. Não se trata de forjar um passado glorioso para o qual devemos voltar, nem de se incorporar acriticamente ao presente moderno do sistemamundo global, mas sim, de propor algo alternativo a partir da reflexão sobre os topos e locus (e chronos) de opressão do passado e do presente, visando um futuro melhor, segundo Gargallo (2014)... Seria isso a utopia cosmopolita e a heterotopia de Santos (2002)? Ou o republicanismo trans-moderno de CastroGómez (2019)? Vejamos a seguir o que seria o republicanismo trans-moderno e deixemos as utopias e alternativas heterotópicas para a última parte desse artigo. 


\section{Modernidade, Modernidades e Trans-Modernidade}

Castro-Gómez (2019) propõe complementar o momento negativo da crítica que Foucault (2004a, 2004b) e pensadoras/es latino-americanas/os do "giro decolonial" fazem à modernidade com o momento positivo da política, como feito por filósofos pós-althusserianos, aproximando-se assim da teoria crítica da democracia radical e do republicanismo. Com isso, distancia-se do movimento modernidade/colonialidade do "giro decolonial" - que ele mesmo havia ajudado a estruturar - ao avançar na direção de uma perspectiva dialética e transmoderna que parta da análise da modernidade enquanto "[...] o resultado do desdobramento de uma multiplicidade de racionalidades históricas diferentes que se cruzam o tempo todo gerando tensões e contradições [e não como algo monolítico]" (CASTRO-GÓMEZ, 2019: 180)18. Ou seja, propõe uma perspectiva que promova a descolonização através do legado moderno - e não desde ou a partir da modernidade, como feito pelas formas de particularismos latinoamericanos de uma vertente do pensamento oriundo do "giro decolonial" que caracteriza a modernidade em bloco como um projeto imperialista, colonialista, patriarcal, genocida, racista, epistemicida e depredador da natureza.

Ora, para o autor, o projeto do "giro decolonial" estaria abrindo mão dos recursos políticos e críticos oferecidos pela própria modernidade por acreditar que esses recursos seriam uma prolongação da lógica capitalista. O erro estaria precisamente em acreditar que a modernidade é um epifenômeno do capitalismo que representou o triunfo final dos ideais políticos da burguesia, o que, para ele, é desconhecer o fato de que, na realidade, a burguesia triunfou porque lutou contra os ideais políticos mais radicais da modernidade, ou seja, contra a ideia do "Estado de direito" que buscava evitar a tirania de qualquer instância em particular (inclusive, a tirania do mercado). Por esse erro de interpretação, segundo Castro-Gómez (2019), defensores/as do neofascismo e do neoliberalismo, assim como críticos/as da modernidade, de modos e em graus diferentes, acabam lutando do mesmo lado contra um inimigo comum - o Estado moderno de direito -, se colocam contra o acesso igualitário real de todos os cidadãos a bens materiais e simbólico e, enfim, negam-se a possibilidade de construir instituições públicas que promovam o combate à desigualdade e à servidão.

Zižek $(2009,2016)$ tratou como uma antinomia da pós-política a falsa necessidade de se ter que escolher entre, de um lado, o modelo neoliberal que "cancela" as instituições republicanas ao mesmo tempo em que guarda uma aparência de liberdade em nome da lógica do mercado e do universalismo e, de outro, um modelo neofascista que também as "cancela", mas sem nenhuma vergonha de fazê-lo em nome dos particularismos e das hierarquias modernocoloniais que sempre negaram a liberdade e a igualdade. Entre os dois modelos, estariam as ruínas das esquerdas, que precisariam ser reerguidas. CastroGómez (2019) sugere uma posição que possa nos tirar da antinomia e nos oferecer uma alternativa política de oposição, pela via da defesa dos valores republicanos, um republicanismo que ultrapasse a modernidade eurocentrada. Para ele, é necessário que os povos e sujeitos explorados pela expansão modernocolonial europeia se apropriem da universalidade abstrata do republicanismo moderno e a tornem concreta por meio da luta política, num cenário agora trans-moderno. Ou seja, ao invés de abandonar os valores republicanos, tais como os valores de "igualdade" e "liberdade", como vem sendo feito, é preciso

${ }^{18}$ Tradução livre do espanhol: “[...] el resultado del despliegue de una multiplicidad de racionalidades históricas diferentes que se cruzan todo el tiempo generando tensiones y contradicciones.” 
reativá-los em outros cenários ou sobre novas bases, o que seria uma postura verdadeiramente descolonial.

A emancipação passaria segundo Castro-Gómez (2019), pela luta contra o universalismo eurocêntrico, em nome de uma universalidade política que combata a desigualdade e as matrizes de dominação. No multiculturalismo liberal, as lutas acontecem no seio das identidades e do marco que produz as desigualdades sociais, sem questionar esse marco. Seria preciso recorrer à "universalização dos interesses" (ŽIŽEK, 2009, 2016) para combater esse marco que organiza de forma desigual as sociedades: as lutas identitárias (de raça, classe, religião, gênero e orientação sexual) não poderiam ter como objetivo político a afirmação da identidade e se ver, ao mesmo tempo, como lutas progressistas, pois estariam deixando intacto o próprio sistema relacional de forças no qual se inscrevem as hierarquizações dos particularismos, já que, como afirma Laclau (2011), as identidades são cristalizações temporárias dessas relações sistêmicas de poder.

Desse modo, a luta pela transformação da situação subalterna passaria pela transformação do sistema de relações de poder a partir do qual as comunidades identitárias são delimitadas como subalternas. Por essa razão, Castro-Gómez acredita que a posição política descolonial de fato não é aquela que busca somente a "recuperação" da identidade cultural dos povos colonizados, já que foi a própria configuração do sistema-mundo moderno-colonial que teria criado as identidades de cada um dos elementos que entrou nessa matriz de relações hierarquizadas: "[afirmar] a diferença retirando-a da rede de antagonismos que a torna possível somente para contemplá-la como um objeto puro e distante é que é uma representação colonial"19 (CASTRO-GÓMEZ, 2019: 69) e nada emancipadora. Junto com Žižek (2001), Castro-Gómez (2019) confirma que os poderes coloniais europeus irromperam violentamente sobre os mundos não europeus, destruindo o tecido cultural das suas experiências. Mas, para esses autores, a resistência política a essa irrupção deve lançar mão da linguagem do colonizador, ao invés de procurar voltar à linguagem prévia à colonização.

Dever-se-ia, com efeito, radicalizar a universalidade - contra o universalismo - e universalizar o ponto de exclusão, e não negar a universalidade e voltar aos particularismos da situação pré-colonial como uma espécie de origem pura de uma identidade cultural perdida. Trata-se de se apropriar da universalidade da modernidade euro-norte-americana imposta de modo abstrato para construir, agora sim, uma universalidade verdadeiramente concreta e plural. A universalidade só se torna efetiva quando é apropriada por aquelas/es que dela foram deixadas/os de fora, donde a necessidade de se realizar a luta pela descolonização por meio da universalização de interesses, segundo esses autores. A melhor forma de combater o colonialismo e o eurocentrismo seria, então, não o encerramento sobre os particularismos culturais e a negação da universalidade, mas, ao contrário, a luta pela afirmação da universalidade concreta e por sua realização, que se constrói por meio das particularidades (LACLAU, 2011).

Em todas as sociedades, haveria sujeitos que não se encaixam no ordenamento que a sociedade em questão considera como sendo útil, normal, funcional ou desejável, aqueles/as cuja voz não é validada e também aqueles/as que vivem na "zona do não ser" (FANON, 1952), ou na "exterioridade" (DUSSEL, 2015), aqueles/as que habitam as margens do Estado e, precisamente em razão do antagonismo, permitem que o Estado se imponha como legítimo detentor do poder de legitimar (DAS e POOLE, 2004). As discursividades médico-científicas

19 Tradução livre do espanhol: "[...] la diferencia pero sacándola de la red de antagonismos que la hace posible para contemplarla como un objeto impoluto y distante, no es cosa que una representación colonial”. 
e jurídico-morais e as moralidades religiosas estariam na base de legitimação e de naturalização desse ordenamento: a governamentalidade biopolítica moderna e liberal. O momento de realização da política é precisamente aquele em que esses sujeitos questionam o ordenamento social que os/as marginaliza, silencia ou oculta. Não questionam somente a marginalização, o silenciamento e a ocultação, mas o próprio ordenamento que gerou a marginalização. Ou seja, não se trata de reivindicar a "inclusão", mas sim, a ruptura com a ordem normativa estabelecida e, ao fazê-lo, combate-se em prol de todos os sujeitos daquela sociedade contra a própria ordem hegemônica. Isso seria o agir de forma concreta, de que trata Castro-Gómez (2019), não somente baseando-se em abstrações, como as que afirmam que todos os homens são racionais, livres e iguais - princípios abstratos das declarações modernas de direitos humanos.

Ao agir como qualquer outro/a humano/a, esses sujeitos estão não somente reivindicando o seu direito de existir como são, mas principalmente, o direito de ser humanos/as, como quaisquer outras/os/es humanas/os/es. Estamos aqui bem no âmago do universal: não se trata de um discurso que coloca ênfase na diferença, mas na desigualdade e, assim fazendo, acaba por servir para todas/os/es as/os/es que são tratadas/os/es de forma desigual e não somente para o coletivo particular de pertencimento identitário daqueles sujeitos. Por essa razão, uma política realmente emancipatória não é aquela que luta somente pelo reconhecimento das formas particulares, mas aquela que propõe sobretudo alternativas para combater o marco que organiza de forma desigual a vida social.

Castro-Gómez (2019) retoma a noção de trans-modernidade de Dussel (2015) para refletir sobre uma alternativa emancipatória, republicana. O "giro decolonial" prega que o colonialismo é a essência da modernidade. Para Dussel, no entanto, seria preciso ser trans-moderno, não anti-moderno (pelo menos, num primeiro momento), já que a modernidade é um fenômeno irreversível, do qual nenhuma cultura poderia, nos dias de hoje, escapar. A hegemonia cultural promovida pela modernidade acabou, de fato, fazendo com que muitas manifestações culturais pelo mundo afora se transformassem em função das imposições modernas (algumas podem ter desaparecido, mas outras muitas se transformaram). O que Dussel chama de trans-modernidade é justamente esse literal atravessamento da modernidade pelas diferentes culturas então subalternizadas, esses "outros" silenciados e ocultados pela modernização hegemônica euronorte-americana. A trans-modernidade seria, dessa forma, para Castro-Gómez (2019), a negação da negação, "[...] a assimilação criativa e emancipadora da modernidade do ponto de vista das histórias locais [...]", ou seja, “[...] uma modernidade vivida desde a exterioridade relativa que nega sua forma ocidentalista e eurocentrada. Uma modernidade, por fim, descolonizada." (2019: 85) ${ }^{20}$. Trata-se, logo, de um projeto político, econômico, social e cultural que prevê, não o retorno aos valores anteriores à colonização, mas uma problematização que, de um lado, interpreta a modernidade eurocentrada localmente a partir das histórias negadas pela modernidade, e de outro lado, ao mesmo tempo, as próprias culturas subalternizadas se reinterpretam, já transformadas pela história eurocentrada.

Quatro instituições oriundas da modernidade precisariam ser inseridas, segundo Castro-Gómez (2019), nesse cenário para que se realize, de fato, o potencial alternativo da trans-modernidade e, assim, aconteça o real "giro decoloni-

${ }^{20}$ Tradução livre do espanhol: “[...] la asimilación creativa y emancipadora de la modernidad realizada desde historias locales. [...] una modernidad vivida desde la exterioridad relativa que niega su forma occidentalista y eurocentrada. Una modernidad, en últimas, descolonizada.” 
al": a ciência, o Estado de direito, a democracia e a crítica. Pensar a ciência em conjunto com os saberes locais, em particular aqueles relativos aos medicamentos, incentivando um diálogo de saberes, e não rechaçar em bloco a medicina ocidental por considera-la como imperialista, por exemplo. Queiramos ou não, o marco básico da política continua sendo o Estado de direito, donde a necessidade de reformulá-lo, como ocorreu na Bolívia (e no Equador), onde o Estado de direito não desapareceu, mas integrou diferentes formas de autoridade e governo comunitários, gerando um constitucionalismo de um novo tipo. A democracia diz respeito a um imaginário político baseado na "igualdade" e na "liberdade" como valores universais (que nunca foram realmente implementados); deve-se, pois, pensar a democracia como o rechaço de todas as formas de hierarquias de poder que organizam de forma desigual as sociedades. Quanto à crítica, o autor se refere ao exercício da problematização, da desnaturalização daquilo que é tido como dado, a desessencialização das certezas inquestionáveis, o questionamento do sentido único e do senso comum através da arte, do debate de ideias, da filosofia, etc. Para transcender o republicanismo moderno, é preciso que as/os/es "deixadas/os/es por conta" por causa do processo de expansão moderno-colonial europeu, as/os/es subalternizadas/os/es, se apropriem da universalidade abstrata do republicanismo e a tornem concreta num cenário trans-moderno.

Seria esse o caminho para o questionamento dos arbitrários culturais sobre os quais se assentam o binarismo de gênero, o dimorfismo sexual e a heteronormatividade? Considerando-se as observações de Balibar (2010) e Prado (2018) sobre a centralidade do (mono)teísmo e, sobretudo, do cristianismo na formação das moralidades modernas que legitimaram a expansão colonial e ainda legitimam as múltiplas modalidades da colonialidade, em associação com as discursividades médico-científicas e jurídico-morais modernas euro-norteamericanas, sugiro que o caminho para o questionamento da naturalização e da essencialização das "zonas do não ser", da "exterioridade" e das "margens" poderia passar pelo (re)avivamento de novas utopias cosmopolitas (Santos, 2002) por meio das alternativas heterotópicas, a partir da ideia de heterotopia de Foucault (2013) e de Santos (2002), cuja base política poderia ser o republicanismo trans-moderno de Castro-Gómez (2019).

\section{Utopias Cosmopolitas e Alternativas Heterotópicas}

(Re)Avivar as utopias por um mundo mais solidário e comunitário é o que sugerem Mandujano (2012) e Santos (2002). Não se trata da "utopia conservadora”, aquela que baseia sua prática na conservação do status quo, na lógica do mercado e nos princípios (neo)liberais. Trata-se da "utopia como heterotopia", com enfoque na emancipação e na participação através das pautas da comunidade e da solidariedade: "[e]nquanto a utopia conservadora tem como princípio a regulação e o retorno aos valores da liberdade moderna, a heterotopia se funda na oposição e na construção da alternativa do sentido comum. Em outras palavras: emancipação como origem e efeito." (MANDUJANO, 2012: 162) 21.

Santos (2002) define a utopia não como uma utopia comum, uma "ortotopia", mas como uma "heterotopia": "[e]m vez da invenção de um lugar situado algures ou nenhures, proponho uma deslocação radical dentro do mesmo lugar:

${ }^{21}$ Tradução livre do espanhol: "Mientras que la utopía conservadora toma como principio la regulación y el regreso a los va- lores de la libertad moderna, la heterotopía se funda en la oposición y en la construcción de la alternativa a través del sentido común. En otras palabras: la emancipación como origen y efecto”. 
o nosso. Partir da ortotopia para a heterotopia, do centro para a margem." (SANTOS, 2002: 333) Com isso, Santos objetiva "[...] experienciar a fronteira da sociabilidade enquanto forma de sociabilidade" (2002: 333) e, assim, que se pense nos modos alternativos de conhecimento geradores de práticas sociais alternativas para se inventar uma subjetividade pelo topos de um "conhecimento prudente para uma vida decente" (Santos, 2004) contra a situação colonial persistente e a modernidade euro-norte-americana hegemônica no âmbito do "pensamento abissal” (SANTOS, 2007).

Se "[o] corpo humano é o ator principal de todas as utopias" (FOUCAULT, 2013: 12), não é difícil entender as investidas governamentais para a definição de uma utopia nacional de corpos saudáveis e de boas almas, ou seja, a produção de um regime de verdade que naturalize o dimorfismo sexual, o binarismo de gênero e a heteronormatividade como efeitos incontestes de uma forma de biopoder sobre a qual se assenta a utopia conservadora (MANDUJANO, 2012; SANTOS, 2002) ao estipular as suas coesões morais e ordens sociais. As heterotopias, para Foucault, seriam "[...] lugares que se opõem a todos os outros, destinados, de certo modo, a apagá-los, neutralizá-los ou purificá-los” (2013: 20), ou seja, contraespaços "[...] de contestação dos outros espaços" (2013: 28). Estendendo o sentido do conceito de heterotopias, para além de Santos (2002) e Foucault (2013), proponho considera-las, despregando-as dos lugares e espaços, como ações, símbolos, pensamentos e sensações que compõem paisagens sociais.

As paisagens heterotópicas seriam, nessa minha proposta, "[...] conjunto[s] variado[s] de elementos relacionados" (INGOLD, 2000: 195) que remetem à formação de biografias individuais através da memória e das experiências cotidianas e que são compartilhados socialmente (TILLEY, 1994) para fazer face às distopias e/ou utopias conservadoras hegemônicas e seus sistemas de dominação. As paisagens heterotópicas parecem se multiplicar, como modalidades de resistência criativa, no seio mesmo das instâncias de produção e manutenção das utopias conservadoras e suas práticas de poder distópicas reinantes (de opressão, ocultamento seletivo, silenciamento e desumanização), ou seja, no âmago da corpopolítica, da biopolítica e da geopolítica - e seus desdobramentos necróticos - que definem as coesões morais, ordens sociais e as governamentalidades hegemônicas a nível individual, coletivo e transnacional na contemporaneidade.

Por governamentalidade, Foucault (2004a: 111-112) entende:

\begin{abstract}
o conjunto constituído pelas instituições, procedimentos, análises e reflexões, cálculos e táticas que permitem exercer uma forma bem específica, embora muito complexa, de poder que tem por alvo principal a população, [tem] por forma maior de saber a economia política, [tem] por instrumento técnico essencial os dispositivos de segurança [...]. A tendência, o cabo de força que, no Ocidente, não parou de conduzir, desde há muito tempo, em direção à preeminência desse tipo de poder chamado de "governo" sobre todos os outros. ${ }^{22}$
\end{abstract}

Dispositivo, por sua vez, seria, para o autor, o conjunto heterogêneo que engloba “[...] discursos, instituições, organizações arquitetônicas, decisões regulamentares, leis, medidas administrativas, enunciados científicos, proposições

${ }^{22}$ Tradução livre do francês: “[...] l'ensemble constitué par les institutions, les procédures, analyses et réflexions, les calculs et les tactiques qui permettent d'exercer cette forme bien spécifique, quoique très complexe, de pouvoir qui a pour cible principale la population, pour forme majeure de savoir l'économie politique, pour instrument technique essentiel les dispositifs de sécurité [...]”; e “[...] la tendance, la ligne de force qui, dans tout l'Occident, n'a pas cessé de conduire, et depuis fort longtemps, vers la prééminence de ce type de pouvoir qu'on peut appeler le "gouvernement" sur tous les autres [...]." 
filosóficas, morais, filantrópicas" (1998: 244) que pode ter por função estratégica a produção de verdades com efeitos de poder sobre os corpos, as populações e os Estados, tornando-se assim biopolítico. A governamentalidade seria, logo, esse governo peculiar dos corpos, das populações e dos Estados marcado por dispositivos biopolíticos instituído pela modernidade ocidental - e eu acrescentaria que a governamentalidade é defendida como ideologia, com base, inclusive, em dispositivos religiosos.

Castro-Gómez (2019) resume a concepção do poder de Foucault em três níveis: no primeiro, chamado de microfísico ou corpo-político, atuam tecnologias de disciplina dos corpos que tendem a produzir uma subjetividade autônoma; no segundo, mesofísico ou biopolítico, operam dispositivos de segurança internos que são a condição sine qua non para a instauração da governamentalidade do Estado moderno e do controle que ele exerce sobre a população num determinado território; e enfim, no terceiro, macrofísico ou geopolítico, funcionam os dispositivos de regulação supra-estatais ou externos voltados para favorecer a "livre concorrência" na apropriação dos recursos naturais e humanos do planeta. Desde o século XVIII, a biopolítica foi e ainda é responsável pelos discursos sobre a superioridade física, étnica e moral de certas populações em relação a outras, estabelecendo a racialização e a sexualização hierarquizadas como verdadeiras estratégias de guerra, segundo Foucault (2004a, 2004b), e o racismo e o sexismo como dispositivos a serviço da melhoria da saúde e da produtividade da população, o que requer a eliminação sistemática das populações consideradas biologicamente e moralmente inaptas.

A Igreja (cristã) dispensava as promessas de salvação e segurança através das técnicas de governo do poder pastoral até o desenvolvimento dos Estados modernos. A partir daí, a governamentalidade biopolítica passa a ressignificar a salvação e a segurança com a criação de dispositivos de segurança internos ("dispositivos de polícia”) que permitem ao Estado exercer um controle racional sobre as epidemias, a fome, a guerra, o desemprego, a inflação e tudo o que possa ameaçar o bem-estar da população, além de criar dispositivos de segurança externa ("dispositivos diplomático-militares"), responsáveis por fazer aumentar o poder de cada Estado, uns em relação aos outros. Trata-se não mais de um sistema internacional baseado na supremacia de um Estado, ao qual todos os outros deveriam se submeter, mas de um sistema que deve tornar possível a concorrência entre os Estados sem que a segurança interna de cada um seja colocada em perigo (FOUCAULT, 2004a, 2004b). É assim que, segundo CastroGómez (2019), a Europa se torna, não uma entidade geopolítica anterior às relações coloniais de poder, mas o produto dessas relações, ou seja, um desses dispositivos de segurança supra-estatal instituidor do que Wallerstein (2006) designou como o sistema-mundo moderno-colonial enquanto um regime de poder global.

Castro-Gómez (2019) mostra que foi a partir daí que Foucault pôde analisar o surgimento do liberalismo no final do século XVIII, não como uma ideologia política, mas como uma prática de governo das populações que buscava substituir o controle-das-populações pela regulação-dos-Estados: a função do Estado deixava de ser a de controlar de forma policial a vida social, mas a de laisserfaire os indivíduos e que seus interesses se desenvolvessem a ponto de concorrerem entre si, o que, em último caso, beneficiaria o próprio Estado. Ou seja, tratava-se de regular a liberdade, não limitá-la. Nesse contexto, o colonialismo não se reduzia mais simplesmente à dominação territorial da Europa em relação a suas colônias, mas englobava também a dominação do mercado no que dizia 
respeito às relações e trocas econômicas no nível planetário. Desse modo, segundo Castro-Gómez (2019), as tecnologias liberais e neoliberais de governo contribuiriam, até a atualidade, para a desterritorialização do colonialismo, através da geopolítica, ao que eu acrescentaria que contribuiriam, logo, para a consolidação e a persistência das múltiplas formas de colonialismos internos, colonialidade e também de imperialidade (nas relações transnacionais), como apontado por Ballestrin (2017).

Castro-Gómez (2019) propõe que se chame toda essa análise do poder de heterárquica, por comparação às teorias hierárquicas a partir das quais vem-se pensando a colonialidade. Ou seja, contrariamente à ideia do sistema-mundo, por exemplo, de Wallerstein (2006), que instala o poder em um dos três níveis vistos acima (corpopolítico, biopolítico ou geopolítico) como estruturador dos demais níveis, fazendo com que o nível macro domine os níveis meso e micro, a visão heterárquica sugerida na análise foucaultiana do poder, ao contrário, permitiria pensar a vida social como um conjunto de agenciamentos ou dispositivos que funcionam de acordo com lógicas distintas e que estão interconectadas de forma parcial ou rizomática.

O poder colonial, de acordo com Castro-Gómez (2019), não poderia ser entendido unicamente através da determinação da relação entre trabalho e capital, mas deveria ser apreendido de forma complexa como um pacote de múltiplas formas de poder: a colonialidade do poder não se reduziria à dominação exercida pelas potências hegemônicas do sistema-mundo sobre os territórios periféricos (o que seria o "colonialismo"), mas estaria ligada aos dispositivos de controle das populações que funcionam no nível biopolítico e aos dispositivos disciplinares que atuam no nível corpopolítico. Não existiria "uma" colonialidade do poder, mas diversos dispositivos coloniais, cuja análise dependeria do grau de generalidade considerado (micro, meso ou macro). Para o autor, o problema da análise do sistema-mundo moderno-colonial em termos hierárquicos é que tende a conferir-lhe um poder totalizador, investindo-o de um caráter sagrado e, assim, desconsiderando-se as ações nos níveis dos e sobre os corpos, populações e Estados.

Balibar (1988) sugere que os Estados nacionais modernos são produtos da colonização, pois que todos foram colonizados ou colonizadores de alguma forma, ou os dois ao mesmo tempo. Esses Estados se universalizaram com o expansionismo europeu entre os séculos XVI e XX, baseando-se, como apontado por Quijano (2000) e Wallerstein (2006), na exploração - colonial, imperial e capitalista - de uma maioria por uma minoria. Isso se deu por meio do controle bio(necro)político dos corpos através dos regimes de verdade instauradores da ideologia e da hierarquia raciais, do binarismo de gênero e da heteronormatividade, dentre outros dispositivos sustentados por e sustentadores das discursividades médico-científicas e jurídico-morais e das moralidades religiosas ocidentais (FOUCAULT, 2004A, 2004B; MBEMBE, 2018). Desse modo, o Estado se relaciona com a sexualidade elaborando as tecnologias de poder/saber da governamentalidade que servirão para o controle da população e de seus corpos por meio de mecanismos de segurança e de coerção situados em um território (FOUCAULT, 2004a, 2004b).

Os Estados nacionais ocidentais serão considerados como “civilizados” por defenderem o ideal dos direitos humanos e as liberdades individuais e agenciarem até mesmo algumas formas identitárias baseadas nas experiências da diversidade sexual e de gênero, sempre em nome da verdade científica e da segurança jurídica (e também, até certo ponto, da moralidade religiosa). Por oposição, os 
Estados não ocidentais serão designados como “incivilizados" por manterem a população ou parte dela sob o jugo de mecanismos violentos de segurança para garantir a integridade soberana do território nacional, grande parte das vezes legitimando o uso da coerção em nome da religião e da tradição. Os primeiros são vistos como os portadores da felicidade universal, ao passo que os últimos são vistos como "outros", promotores do ódio; e assim se normaliza a branquidade heterossexual euro-norte-americana como expressão "natural" da civilização e dos "verdadeiros" valores humanos (DABASHI, 2011). Em ambos os casos, estamos diante de formas de governamentalidades biopolíticas herdadas da modernidade euro-norte-americana, embora as primeiras se vejam mais "evoluídas" (democráticas) por já terem sido como as segundas no passado (autoritárias), reproduzindo, ainda nos dias de hoje, uma modalidade estranha do darwinismo social.

A relação entre Estado e sexualidade mediada pelo controle social não seria exclusiva dos regimes políticos considerados pelos Estados ocidentais como opressores, mas estaria na base existencial de todos os Estados nacionais, inclusive ocidentais, sempre criadores de algum tipo de homo sexualis, assim como instituíram os "legítimos" homo œeconomicus, homo politicus, homo religiosus, enfim, o homo nationalis... modernos e ocidentais.

Para existir enquanto instrumento de governo, que promove a felicidade para alguns ao mesmo tempo em que tem o poder de limitá-la para outros, o Estado necessita uma base simbólica que acomode as suas práticas de poder de modo a não ser questionado, a saber, uma ideologia nacional que atribua sentidos às tecnologias de poder/saber e aos dispositivos biopolíticos estatais. É aí que vem entrando em cena o homonacionalismo ou a maneira como alguns Estados incorporam situacionalmente a defesa de certas expressões da diversidade sexual e de gênero ao seu aparato de nation-building. Puar (2007) adverte que o homonacionalismo de países norte-americanos e europeus, por exemplo, pode ser uma falácia ocidental elaborada por políticos dos grupos dominantes para fins de legitimação de suas pretensões expansionistas (com viés moralizador), como no momento da "guerra ao terrorismo" logo após o 11 de setembro de 2001, ao encamparem algumas reinvindicações identitárias homossexuais ou queer. Esses países desenvolveram, desse modo, uma política representacional hegemônica (nada participativa) como um forma de se mostrar mais "civilizados", guardiães dos "direitos humanos", em relação a países definidos, por conseguinte, como "incivilizados", aqueles que supostamente promoviam o terrorismo e não respeitavam os direitos humanos, ou seja, não respeitavam a diversidade sexual e de gênero. Mas ao fazê-lo, segundo Puar, ocultam-se totalmente as tensões internas a cada país ocidental relacionadas aos modos múltiplos de se experimentar a diversidade sexual e de gênero localmente e não se percebe o tratamento diferenciado dado pelo Estado, através dos dispositivos biopolíticos, a essa multiplicidade, valorizando uma certa "sexualidade respeitável" em detrimento de todas as outras formas - as heterotópicas -, valorizando geralmente uma sexualidade normativa.

No Brasil, percebe-se que a experiência da diversidade sexual ora é tratada por instâncias estatais como digna de respeito - por exemplo, quando o Supremo Tribunal Federal reconhece a união civil entre pessoas do mesmo sexo/gênero como merecedora dos mesmos direitos outorgados ao casamento -, ora é tratada pelas mesmas ou outras instâncias estatais com desdém - por exemplo, quando se impede a divulgação em escolas, por motivos religiosos, de uma cartilha contra a discriminação por orientação sexual. Para Puar (2007), 
em certos momentos, o Estado pode se servir desse caráter respeitoso para internacionalmente ser reconhecido como "civilizado", de acordo com padrões modernos e ocidentais. Mas ao fazê-lo, o que está sendo transformado em exemplo nacional não condiz, de fato, com a diversidade da realidade local: geralmente, escondem-se as relações de poder internas que içaram certas práticas à condição de exemplares, em detrimento daquelas que foram então voluntariamente mantidas ocultas, silenciadas ou enquadradas. E assim se reproduz o homonacionalismo, como um desdobramento da geopolítica global, baseado nos valores brancos, masculinos, consumistas, cristãos, urbanos, elitistas, imperialistas euro-norte-americanos e... até mesmo queer.

\section{À guisa de perspectivas}

O Estado pode desocultar e legitimar como "sexualidades saudáveis" e identidades correlatas somente aquelas representativas do mundo moderno ocidental, geralmente modeladas pela urbanidade, a branquidade e a heteronormatividade, e por conseguinte, manter na invisibilidade todas as outras formas alternativas. É assim que os Estados nacionais, cuja governamentalidade já é caracterizada pela biopolítica moderna e (neo)liberal que promove a necropolítica (MBEMBE, 2018) e pela biopolítica pós-política que fomenta mais o medo do que a vida (ŽIŽEK, 2009), tornam-se artífices, no âmbito do capitalismo global, da geo(necro)política ${ }^{23}$, ou seja, de dispositivos de regulação voltados para favorecer a "livre concorrência" no controle da vida e na disciplina da morte.

No Cazaquistão, uma ex-república soviética, a construção da identidade nacional após a independência, em 1991, implicou na produção de símbolos representativos. Com a independência, o país passou a se pautar no modelo estatal de governamentalidade biopolítica vigente nos países ocidentais e reavivou a moralidade religiosa (islâmica) desfavorecida durante o passado soviético, sem deixar totalmente de se espelhar na vizinha Rússia, já que uma proporção importante da população do novo país é de origem russa. Grande parte dos símbolos da nação foram escolhidos em referência à maioria étnica turco-mongol e, em menor grau, em referência ao passado islâmico, mas um mereceu destaque especial: o "homem dourado". Trata-se de um esqueleto de um suposto guerreiro cita de mais de 2.000 anos encontrado em 1969 e, agora, alçado a herói nacional ${ }^{24}$.

Ora, recentemente, foi descoberto que não se tratava de um príncipe, mas sim, de uma mulher guerreira, talvez uma princesa, que viveu em uma sociedade que contrastava pouco a diferença entre homens e mulheres e não discriminava as práticas sexuais entre pessoas do mesmo sexo/gênero. Gerou-se um desconforto, já que o país tentava se inserir no rol das nações adotando os discursos médico-científicos e jurídico-morais modernos ocidentais e algumas concepções hierarquizadas de gênero, legitimadas pela moralidade religiosa islâmica agora reavivada, para reinterpretar o passado turco-mongol (no qual supostamente os homens comandavam e as mulheres eram comandadas) e se distinguir do passado soviético (que, de alguma maneira, viabilizava uma "certa" igualdade de gênero e fazia vista grossa para as práticas sexuais entre pessoas do mesmo sexo/gênero, embora essa não seja a realidade russa atual). Com isso, desenvolvem-se formas heterotópicas de valorização tanto do passado turco-

${ }^{23}$ Osuri (2008) usa "geo/necropolitics" num sentido um pouco diferente do proposto aqui para caracterizar as históricas relações de dominação da Austrália sobre o Timor Leste baseadas na raça.

24 Nessa parte, evitarei elencar as referências bibliográficas que respaldam algumas afirmações, já que se encontram citadas nos textos que publiquei ou estão em fase de edição sobre os assuntos tratados (Gontijo, 2018a, 2019b, 2020, 2021a; 2021b). 
mongol, quanto do passado soviético, contra as hierarquizações que se impõem no país, como abordado em detalhe em outro texto (GONTIJO, 2018a).

No Quirguistão e na Ucrânia, países que nasceram também a partir do esfacelamento da União Soviética, assim como na Mongólia, país que esteve na zona de influência direta da União Soviética, a independência e os anos seguintes representaram momentos de negociação conflitiva da identidade nacional em relação à Rússia, no que diz respeito às performances de gênero e à diversidade sexual. Nos três casos, há a busca de materiais simbólicos do passado présoviético para legitimar a independência, mas materiais cuidadosamente selecionados para se distinguir da Rússia e se aproximar do Ocidente na modelagem do Estado nacional e da governamentalidade a ser adotada.

Sabe-se que a governamentalidade vigente na Rússia pós-soviética, sobretudo sob a autoridade do Presidente Putin, busca condenar as expressões da diversidade sexual e de gênero e até mesmo rever o papel das mulheres na vida social, rebaixando-as, numa associação declarada entre Estado, religião cristã ortodoxa e militarismo. A Rússia tem obtido certo êxito em impor, em suas relações políticas e econômicas com ex-repúblicas soviéticas da Ásia, a condenação expressa da homossexualidade, por meio das chamadas leis "contra a propaganda gay”. Assim, a Rússia define suas zonas de influência e demarca a diferença em relação à hegemonia ocidental, já que, no mundo ocidental, o homonacionalismo recomenda, mais ou menos oficialmente de acordo com o jogo geopolítico do momento, que os países sob a sua influência declarem as suas intenções para com suas e seus cidadãos homossexuais ao adotarem o Estado moderno de inspiração euro-norte-americana.

É nesse sentido que, durante a Revolução de 2014 que levou à consolidação da aproximação da Ucrânia com a Europa em detrimento do estreitamento das relações com a Rússia, viam-se bandeiras representativas de pessoas lésbicas, gays, intersexuais, queers e transexuais/transgêneres (LGBTQI+) nas manifestações em prol da Europa. Mas, nos anos que se seguiram, as paradas do orgulho LGBTQI+ na capital, Kiev, foram violentamente repudiadas por partidários de movimentos de extrema-direita e de religiosos cristãos ortodoxos, muitos deles pró-Europa, como relatei em outro texto (GONTIJO, 2020). O mesmo acontece na Moldávia, outra ex-república soviética que passa pelo mesmo dilema de aproximação com a Europa e distanciamento da Rússia. A heterotopia aqui está, por exemplo, na própria maneira como algumas pessoas LGBTQI+ se organizam em movimentos sociais, tentando agenciar a relação entre a tradição e o pertencimento nacional (para trazer à tona algumas formas de liberalidade em relação à sexualidade vividas no passado que ajudem a denunciar a interpretação religiosa fundamentalista do presente) e as modalidades do homonacionalismo (em particular, dos organismos internacionais, que têm dificuldade em lidar com as particularidades das experiências locais), como observei também na Mongólia.

Sobre as múltiplas realidades africanas, nota-se, de um lado, a ideia globalmente difundida de que a África pós-colonial é um ambiente homofóbico e, de outro, a ideia localmente disseminada de que as práticas e identidades sexuais não normativas e a homossexualidade são exógenas ao continente e teriam sido levadas para lá pelos processos de colonização árabe-muçulmano e europeucristão; e enfim, há ainda a acepção falaciosa de que as pessoas africanas são luxuriosas e seus corpos, objetos "naturalmente" eróticos. Com efeito, a categoria "homossexualidade" pode ser tratada como exógena à história africana, já 
que foi forjada no contexto europeu de consolidação do Estado nacional moderno, como abordado acima.

A descolonização e a "nova ordem mundial" do sistema-mundo, a partir da segunda metade do século XX, levaram as nações africanas à adoção do modelo estatal ocidental com a manutenção de boa parte de sua estruturação ideológica baseada naqueles dispositivos biopolíticos da governamentalidade moderna, ainda que com significativas nuances, inclusive a conservação da moralidade religiosa cristã (e islâmica) da colonização, donde a defesa, por parte desses novos governantes e das instituições de governo, da suposta exogenia da diversidade sexual e de gênero e o conseguinte desenvolvimento de propósitos homofóbicos. As paisagens heterotópicas africanas denunciam o caráter ocidental demasiadamente universalista e regulador do argumento da homofobia africana generalizada, o caráter nacionalizante excessivamente culturalista do argumento da exogenia das sexualidades não normativas africanas e o caráter racista e essencializador do argumento da "natureza" luxuriosa das/os africanas/os, ao considerar que, em todos os casos, não se atenta para as particularidades das corporalidades e das expressões da diversidade sexual e de gênero no tão diversificado continente, nem a sua relação com as complexas dinâmicas culturais transnacionais contemporâneas, como percebi em minhas pesquisas no continente (GONTIJO, 2021a).

No Irã, a antiga Pérsia, até o século XIX, mesclavam-se os resquícios da "tolerância" dos tempos do Império Aquemênida de Ciro, o Grande, com a liberalidade do islamismo medieval no tocante à diversidade sexual e de gênero: num mundo segregado por gênero, homens e mulheres podiam manter relações afetivas e sexuais com pessoas do mesmo sexo/gênero, o que era exaltado na literatura, nas artes plásticas e em documentos oficiais. A entrada do país na esfera dos interesses (econômicos) ocidentais, iniciada no século XIX, fez com que as discursividades médico-científicas e as normatividades jurídico-morais europeias fossem paulatinamente adotadas, juntamente com a governamentalidade biopolítica moderna: as expressões da diversidade sexual e de gênero passaram a ser patologizadas e banidas, consideradas como lembranças de um passado "arcaico" diante da modernidade promissora, embora tenham se desenvolvido espaços clandestinos de sociabilidades homossexuais nos grandes centros urbanos, assim como acontecia nas cidades ocidentais. Com a revolução de 1979, a queda da monarquia e a instalação de uma república teocrática islâmica, a governamentalidade biopolítica foi mantida, assim como as discursividades médico-científicas e as normatividades jurídico-morais, no que diz respeito à condenação da diversidade sexual e de gênero, mas agora sob os mandamentos do clero xiita, configurando uma modernidade "outra".

No Irã, a intencionalidade da ação bionecropolítica do Estado parece mais explícita do que em países ocidentais e as paisagens heterotópicas despontam como formas desafiadoras de questionamento da naturalização das práticas de poder do Estado, confrontando a própria ideologia de nation-building sustentada lá por aquilo que Foucault (FOUCAULT, 2001) chamou de "espiritualidade política”, como relatei em outro texto (GONTIJO, 2021b): um véu (hijab) que cai propositadamente pelas costas de uma mulher maquiada deixando entrever as mechas de seus cabelos (quando a maquiagem é proibida e o uso do véu cobrindo todo o cabelo é obrigatório); a proliferação de cafés iguais a bares com fotos pequenas do aiatolá em meio a fotos maiores de roqueiros ocidentais nas paredes (quando os bares são proibidos e as fotos do aiatolá em locais públicos são obrigatórias em posição de destaque); a prática corriqueira do download de 
músicas proibidas; a fabricação e a distribuição clandestinas de bebidas alcoólicas (proibidas); a realização de festas privadas proibidas, inclusive festas de gays e lésbicas; o contrabando de literatura ilegal e censurada; o uso de maquiagem feita em salões de beleza subterrâneos (quando os salões são parcialmente proibidos); os aplicativos para encontros entre pessoas para fins sexuais (também proibidos); o uso de VPN para ter acesso a redes sociais proibidas (por meio das redes, mulheres se apresentam, por exemplo, sem véu e dançando em companhia de homens), etc.

Para que o Estado iraniano não perdesse o seu legítimo direito biopolítico sobre os corpos de cada indivíduo, acabou até mesmo legitimando, por meio de uma recomendação religiosa, a cirurgia de redesignação sexual, tornando-a inclusive desejável para os sujeitos homossexuais. Hoje em dia, alguns pais têm preferido nomear os seus filhos com prenomes persas, e não mais árabes, assim como muitas pessoas preferem se cumprimentar, não mais com palavras que remetem a Deus, mas com termos persas pré-islâmicos, como "bedrud" (tchau) ao invés de "khodar(ha)fez" (deus te proteja). Eis algumas performances de paisagens heterotópicas iranianas...

Nas Ilhas Maldivas, por sua vez, a entrada do país na esfera dos interesses ocidentais se intensificou após a independência, em 1965, e durante os anos de governo autoritário até o início da década de 2010. Nesse período, o país, um arquipélago formado por mais de mil ilhas, concedeu algumas dessas ilhas para a exploração turística por empresas hoteleiras estrangeiras. Nessas ilhas-resort, controladas por europeus, norte-americanos, japoneses e sul-coreanos, pode-se, por exemplo, andar livremente de roupas de banho, ingerir bebidas alcoólicas e comer carne de porco. Os/As nativos/as estavam /as de frequentar essas ilhas. Nas demais ilhas, habitadas pela população nativa, estavam e ainda estão proibidas as bebidas alcoólicas e a carne de porco e um estrito código indumentário foi exigido, sob o comando do clero sunita da Arábia Saudita. O turismo estava proibido nas ilhas habitadas por nativos/as até recentemente. Durante algumas décadas, a população nativa foi se adaptando às exigências do governo saudita que impunha práticas biopolíticas até então inexistentes ou que foram fortalecidas: as mulheres passaram a usar o véu ou hijab e até vestimentas que lhes cobrem todo o rosto, niqab; a dança foi permitida somente aos homens; a poligamia foi incentivada; o apedrejamento por adultério e a pena de morte para crianças a partir dos sete anos de idade foi instituída; a censura religiosa e a polícia moral foram ativadas; e mesmo os monumentos e bens patrimoniais préislâmicos que remetiam ao passado budista foram destruídos ou abandonados, etc.

As gerações maldívias mais jovens que não conheceram a realidade de antes desse período teriam reagido de duas maneiras: algumas pessoas teriam se espelhado nas realidades estadunidense e europeia como válvulas de escape, vivendo de forma dissidente e heterotópica, seja no âmbito de espaços de sociabilidade fora do alcance da polícia moral, seja mais radicalmente através da criação de gangues de delinquentes e de usuários/as de substâncias psicoativas ilícitas na capital; outras muitas teriam se rendido ao fundamentalismo islâmico, juntando-se a entidades jihadistas, como a Fundação Islâmica das Maldivas, ou aos exércitos do Estado Islâmico na Síria e no Iraque.

Ao longo da década de 2010, um governo progressista tem tentado promover a aproximação do país com a Índia, o Sri Lanka e a China, como forma de minimizar o poder saudita, além de promover reformas importantes, embora lentas, como a abertura ao turismo das ilhas habitadas por nativos/as. Vê-se, 
por exemplo, o surgimento de barcos ancorados em frente a algumas ilhas propondo bebida alcóolica, mesmo sem que a legislação sobre o consumo de bebidas alcoólicas tenha mudado. Assim como no Irã, os casais de namorados mais jovens aproveitam que a legislação permite casamentos de um dia para manterem, por meio dessas uniões-relâmpago, relações sexuais dentro da legalidade, driblando inclusive a exigência da virgindade feminina - o que faz das Maldivas o país com a maior proporção de pessoas divorciadas do mundo. A diversidade sexual é pouco comentada, mas percebe-se o uso que rapazes homossexuais fazem dos grupos de dança para a expressão de sua sexualidade e as trocas de ideias com turistas nas ilhas habitadas por nativos/as agora abertas ao turismo, como relatei em outro texto (GONTIJO, 2019b).

A imposição de práticas oriundas da interpretação dos textos religiosos parece acabar por assujeitar cada vez mais aqueles grupos que já são vulnerabilizados pelas desigualdades econômicas. Assim, o sunismo nas Ilhas Maldivas, o xiismo no Irã ou o cristianismo ortodoxo na Rússia, quando tornados vertentes religiosas exclusivas de algum Estado biopolítico ou sustentadoras ideológicas do Estado, podem ter efeitos muito semelhantes em termos de submissão de maiorias vulnerabilizadas por elites minoritárias que agem em função de seus próprios interesses, geralmente econômicos, camuflados pelo religioso.

Se há semelhanças evidentes entre o que foi comentado brevemente acima com o contexto atual do Brasil, também brevemente tratado na primeira parte desse artigo, isso não é mera coincidência: são os efeitos da distopia geo(necro)política em funcionamento. Esses efeitos se fazem sentir em todos as partes do planeta e chegam até os mais profundos pontos da Amazônia, onde resido (Gontijo, 2017; Gontijo, Arisi e Fernandes, 2021). E o antídoto para esses efeitos nefastos poderia ser a atualização política trans-moderna das utopias, por meio do florescimento das alternativas heterotópicas.

Recebido em 28 de janeiro de 2021. Aprovado em 19 de abril de 2021. 


\section{Referências}

AMADIUME, Ifi. Re-Inventing Africa: Matriarchy, religion and culture. Londres: Zed Books, 1997.

BALIBAR, Étienne. La Proposition de l'Égaliberté. Paris: PUF, 2010.

BALIBAR, Étienne. "La Forme Nation”. In: BALIBAR, É.; WALLERSTEIN, I. (orgs.). Race, Nation, Classe. Paris: La Découverte, 1988. pp. 117-143.

BALLESTRIN, Luciana. Modernidade/Colonialidade sem 'Imperialidade'? O Elo Perdido do Giro Decolonial. DADOS, 60 (2): 505-540, 2017. Disponível em https://doi.org/10.1590/001152582017127.

CASTRO-GÓMEZ, Santiago. El Tonto y los Canallas. Notas para um Republicanismo Transmoderno. Bogotá: Editorial Pontifica Universidad Javeriana, 2019.

CURIEL, Ochy. "El Régimen Heterosexual y la Nación. Aportes del Lesbianismo Feminista a la Antropología". In: BIDASECA, K.; VAZQUEZ LABA, V. (orgs.). Feminismos y Poscolonialidad: descolonizando el feminismo desde y en América Latina. Buenos Aires: Ediciones Godot Argentina, 2011. pp. 48-93.

CUSICANQUI, Silvia Rivera. Ch’ixinakax Utxiwa: Una reflexión sobre prácticas y discursos descolonizadores. Buenos Aires: Tinta Limón, 2010.

DABASHI, Hamid. Brown Skin, White Masks. Londres: Pluto Press, 2011.

DAS, Veena; POOLE, Deborah. "State and Its Margins: Comparative ethnographies". In: DAS, V.; POOLE, D. (orgs.). Anthropology in the Margins of the State. Oxford: Oxford University Press, 2004.

DUSSEL, Enrique. Filosofias del Sur. Descolonización y transmodernidad. México: Akal, 2015.

FANON, Frantz. Peau Noire, Masques Blancs. Paris: Seuil, 1952.

FERNANDES, Estêvão. Um Debate sobre Feminismos Decoloniais e suas Repercussões para Pesquisas em Povos Indígenas no Brasil. Ártemis, XXVIII (1): 38-51, 2019. Disponível em https://doi.org/10.22478/ufpb.18078214.2019v28n1.45286

FERNANDES, Estêvão; GONTIJO, Fabiano. Diversidade Sexual e de Gênero e Novos Descentramentos: um manifesto queer caboclo. Amazônia: Revista de Antropologia, 8 (1): 14-22, 2016. Disponível em http://dx.doi.org/10.18542/amazonica.v8i1.4722

FOUCAULT, Michel. O Corpo Utópico, as Heterotopias. São Paulo: n-1 Edições, 2013.

FOUCAULT, Michel. Sécurité, Territoire, Population. Cours au Collège de France (1977-1978). Paris: Gallimard / Seuil, 2004a.

FOUCAULT, Michel. Naissance de la Biopolitique. Cours au Collège de France (1978-1979). Paris: Gallimard / Seuil, 2004b. 
FOUCAULT, Michel. Dits et Écrits - Vol. II (1976-1988). Paris: Gallimard, 2001.

FOUCAULT, Michel. Microfísica do Poder. Rio de Janeiro: Graal, 1998.

GARGALLO, Francesca. Feminismos desde Abya Yala. Ideas y Proposiciones de las Mujeres de 607 Pueblos en Nuestra América. Ciudad de México: s/e, 2014.

GONTIJO, Fabiano. "Diversidade Sexual e de Gênero, Estado Nacional e Biopolítica no Sul Global: lições da África”. Anuário Antropológico, II, 2021a (em edição).

GONTIJO, Fabiano. Diversidade Sexual e de Gênero, Estado Nacional e Paisagens Heterotópicas no Irã: Foucault e depois. Afro-Ásia, 63, 2021b (em edição).

GONTIJO, Fabiano. Nação, Simbolismo e Revolução na Ucrânia. Revista de Antropologia, 63 (3), 2020. Disponível em https://doi.org/10.11606/16789857.ra.2020.178853

GONTIJO, Fabiano. Queer or Not Queer? Diversidade Sexual e de Gênero, Estado e Antropologia. Novos Debates, 5 (1-2): 80-92, 2019a. Disponível em http://abant2.hospedagemdesites.ws/novos_debates/wpcontent/uploads/2020/09/F2.-Fabiano-Gontijo.pdf

GONTIJO, Fabiano. Política, Nação e Gênero nas Ilhas Maldivas. Revista de Antropologia, 62 (3): 610-651, 2019b. Disponível em https://doi.org/10.116o6/2179-0892.ra.2019.165234

GONTIJO, Fabiano. Nation-Building, Gênero e Política no Cazaquistão: o caso do Homem Dourado. Mana, 24 (3): 151-185, 2018a. Disponível em https://doi.org/10.1590/1678-49442018v24n3p151

GONTIJO, Fabiano. Biologia, Direito, Perspectiva Queer e Intersexualidade. Teoria Jurídica Contemporânea, 3 (1): 120-139, 2018b. Disponível em https://doi.org/10.21875/tjc.v3i1.18105

GONTIJO, Fabiano. Gênero, Sexualidade e Etnodesenvolvimento na Amazônia. Revista FSA, 14 (5): 55-72, 2017. Disponível em: http://dx.doi.org/10.12819/2017.14.5.3

GONTIJO. Fabiano; ARISI, Barbara; FERNANDES, Estêvão. Queer Natives in Latin America. Cham: Springer, 2021.

GONZÁLEZ CASANOVA, Pablo. "Colonialismo Interno (Una Redefinición)”. In: BORON, A.; AMADEO, J.; GONZÁLEZ, S. (orgs.). La Teoría Marxista Hoy. Buenos Aires: CLACSO, 2006. pp. 409-434.

INGOLD, Tim. "The Temporality of the Landscape". In: INGOLD, T. The Perception of the Environment. Londres / Nova York: Routledge, 2000. pp. 189208.

LACLAU, Ernesto. Emancipação e Diferença. Rio de Janeiro: EdUERJ, 2011.

LUGONES, María. "Colonialidad y Género: hacia un feminismo descolonial". In: MIGNOLO, W. (org.). Género y Descolonialidad. Buenos Aires: Ediciones del Siglo, 2008. pp. 13-55. 
MANDUJANO, Miguel. Frontera al Norte, Utopía al Sur: Paradigma dominante y alternativa cosmopolita. Cuadernos Americanos, 2 (140): 147-165, 2012. Disponível em https://dialnet.unirioja.es/ejemplar/309246

MBEME, Achille. Necropolítica. São Paulo: n-1 Edições, 2018.

MIGNOLO, Walter. "Introducción”. In: MIGNOLO, W. (org.). Género y Descolonialidad. Buenos Aires: Ediciones del Siglo, 2008.

OSURI, Goldie. War in the Language of Peace, and an Australian Geo/Politics of White Possession. ACRAWSA e-journal, 4 (1), 2008. Disponível em: https://www.researchonline.mq.edu.au/vital/access/services/Download/mq:64 74/DSo1?view=true

OYěWÙMÍ, Oyèrònké. The Invention of Women: Making an african sense of western gender discourse. Minneapolis: University of Minnesota Press, 1997.

PAREDES, Julieta. Hilando Fino desde el Feminismo Comunitario. México: Cooperativa El Rebozo, 2014, $2^{\text {a }}$ Edição.

PRADO, Abdennur. Genealogía del Monoteísmo. La Religión como Dispositivo Colonial. México: Akal, 2018.

PUAR, Jasbir K. Terrorist Assemblage: homonationalism in queer times. Durham: Duke University Press, 2007.

PURI, Jyoti. Encoutering Nationalism. Malden: Blackwell Publishing, 2004.

QUIJANO, Aníbal. Colonialidad del Poder y Classificación Social. Journal of World-Systems Research, 6 (2): 342-386, 2000. Disponível em https://doi.org/10.5195/jwsr.2000.228

SANTOS, Boaventura de Sousa. A Crítica da Razão Indolente. Por um Novo Senso Comum. São Paulo: Cortez, 2002.

SANTOS, Boaventura de Sousa (org.). Conhecimento Prudente para uma Vida Decente. São Paulo: Cortez, 2004.

SANTOS, Boaventura de Sousa. Para Além do Pensamento Abissal. Novos Estudos CEBRAP, 79: 71-94, 2007. Disponível em https://doi.org/10.1590/So10133002007000300004

SEGATO, Rita. "Género y Colonialidad: Del patriarcado comunitario de baja intensidad al patriarcado colonial moderno de alta intensidade". In: SEGATO, R. La Crítica de la Colonialidad en Ochos Ensayos e una Antropológia por Demanda. Buenos Aires: Prometeo Libros, 2013. pp. 69-100.

TILLEY, Chris. "Space, Place, Landscape and Perception: phenomenological perspectives. In: TILLEY, C. A Phenomenology of Landscape: places, paths and monuments. Oxford: Berg, 1994, pp. 7-34.

TLOSTANOVA, Madina. "Por qué Cortarse los Piés para Caber en los Zapatos Occidentales?': Las ex colónias soviéticas no europeas y el sistema de género colonial moderno". In: MIGNOLO, W. (org.). Género y Descolonialidad. Buenos Aires: Ediciones del Siglo, 2008. pp. 85-122

VANITA, Ruth. Queering India: Same-sex love and eroticism in Indian culture and society. Londres: Routledge, 2002.

WALLERSTEIN, Immanuel. Comprendre le Monde: introduction à l'analyse des systèmes-monde. Paris: La Découverte, 2006. 
WITTIG, Monique. El Pensamiento Heterosexual y Otros Ensayos. Barcelona: Egales, 2006.

ŽIŽEK, Slavoj. O Sujeito Incômodo. São Paulo: Boitempo, 2016.

ŽIŽEK, Slavoj. Violência - Seis Notas à Margem. Lisboa: Relógio D’Água, 2009.

ŽIŽEK, Slavoj. "Un Alegato Izquierdista Contra el Eurocentrismo". In: MIGNOLO, W. (org.). Capitalismo Y Geopolítica del Conocimiento. Buenos Aires: Ediciones del Signo, 2001. pp. 173-200. 